\title{
EDUCATIONAL QUALITY ASSURANCE MANAGEMENT IN IMPROVING AND DEVELOPING THE MIDDLE SCHOOL PROFESSIONALISM TEACHERS
}

\author{
Deny Setiawan ${ }^{1}$ \\ 1)IAI Sunan Kalijogo Malang \\ 1)denysetiawan3004@gmail.com
}

\begin{abstract}
This article discusses the management of educator quality assurance in improving and developing teacher professionalism conceptually which includes the implementation of recruitment, the development of teacher professions and termination of employment as an important function in ensuring quality education quality. This article is made by reviewing and gathering information from various references to books, articles and journals that are used as material in conceptually studying and adding insight related to educator quality assurance. The management of educator quality assurance is a good step to support the improvement and acceleration of the improvement of the quality of human resources in the field of education in accordance with the need to improve educator standards and quality, but in implementing educator quality assurance management is expected to be balanced between recruitment, professional development, welfare development and termination of employment. There is still a lot of implementation in the field that causes workload and professional development for senior educators, mediators and juniors and creates new problems in education.
\end{abstract}

Keywords: Quality Assurance Management, Education Improvement and Development, Teacher Professionalism

Abstrak. Artikel ini membahas tentang manajemen penjaminan mutu pendidik dalam meningkatkan dan mengembangkan profesionalisme guru secara konseptual yang meliputi pelaksanaan rekrutmen, pengembangan profesi guru dan pemutusan hubungan kerja sebagai fungsi penting dalam menjamin mutu pendidikan yang bermutu. Artikel ini dibuat dengan mengkaji dan mengumpulkan informasi dari berbagai referensi buku, artikel dan jurnal yang digunakan sebagai bahan dalam mengkaji secara konseptual dan menambah wawasan terkait penjaminan mutu pendidik. Pengelolaan penjaminan mutu pendidik merupakan langkah yang baik untuk mendukung peningkatan dan percepatan peningkatan kualitas sumber daya manusia di bidang pendidikan sesuai dengan kebutuhan untuk meningkatkan standar dan mutu pendidik, namun dalam melaksanakan pengelolaan penjaminan mutu pendidik masih kurang diharapkan seimbang antara rekrutmen, pengembangan profesional, pengembangan kesejahteraan dan pemutusan hubungan kerja. Masih banyak implementasi di lapangan yang menyebabkan beban kerja dan pengembangan profesional bagi pendidik senior, mediator dan junior serta menimbulkan masalah baru dalam dunia pendidikan.

Kata Kunci: Manajemen Penjaminan Mutu, Peningkatan dan Pengembangan Pendidikan, Profesionalisme Guru 


\section{คКคDEMIKค \\ Jurnal Manajemen Pendidikan Islam}

INSTITUT AGAMA ISLAM SUNAN KALIJOGO MALANG

P-ISSN 2622-9293 / E-ISSN 2721-9658

Volume 3 Nomor 1 Juni 2021

\section{INTRODUCTION}

As the main figure in the process of education in schools, teachers play a major role in determining the success of students, especially in relation to the process of achieving good learning outcomes. The teacher is the most influential component in creating quality learning processes and results. The main task of a teacher is to educate, teach, guide, direct, train, assess, and evaluate students. ${ }^{1}$ In carrying out its duties, teachers apply expertise, skills that meet certain quality standards or norms obtained through professional education. ${ }^{2}$

Based on research from Sumarsono (2014), we must be aware of the important role of teachers and the growing demand for teacher professionalism, the government establishes various policies aimed at improving teacher quality. ${ }^{3}$ Teacher professional development is very important in improving the quality of education today, given the professionalization of teachers (educators) is a necessity, especially if we look at the current objective conditions relating to various things encountered in carrying out education. The same thing was expressed by Yusra (2013), the world of education is currently in desperate need of professional teachers. This is intended to have educational interaction between teachers and students. ${ }^{4}$

A job can be categorized as a profession if it fulfills a number of conditions, such as needed services, based on a scientific discipline, the trimester must go through sufficient education and training, have a code of ethics, organization, and professional culture. ${ }^{5}$ Among these conditions, the existence of disciplines that underlie a profession is the most important requirement. This is because the level of professionalism of a profession is measured by scientific complexity and the underlying theory.

The education profession functions to fulfill the mandate in the opening of the 1945 Constitution, namely to participate in the intellectual life of the nation in accordance with the differentiation of duties of a modern society. Under Law No. 20 of 2003 Article 39 Paragraph 2 , educators are professionals who are tasked with planning and carrying out the learning

1 Yusuf, M. Dan Ruslan. (2014). Pengaruh kompetensi profesional guru biologi yang telah tersertifikasi terhadap hasil belajar siswa di sma se-kota ternate. Jurnal Bio Edukasi 3(1) ISSN 2301-4678.

${ }^{2}$ Hidayah, F. (2013). Perbedaan tingkat efficacy ditinjau dari status sertifikasi pada guru sekolah menengah atas di Tuban. Jurnal Psikologi Pendidikan 2(1).

3 Sumarsono, R.B. (2014). Pengembangan profesi tenaga pendidik melalui karya ilmiah dalam rangka menuju pendidikan yang bermutu. Jurnal Administrasi Pendidikan FIP UM Prosiding Seminar Nasional.

4 Yusra. (2014). Upaya peningkatan efisiensi tenaga guru profesional dalam pencapaian mutu pendidikan. Jurnal $10(1)$

5 Trianto. (2010). Pengantar Penelitian Pendidikan bagi Pengembangan Profesi Pendidikan dan Tenaga Kependidikan. Jakarta : Kencana Prenada Media Group. 


\section{คКคDEMIKค \\ Jurnal Manajemen Pendidikan Islam}

INSTITUT AGAMA ISLAM SUNAN KALIJOGO MALANG

P-ISSN 2622-9293 / E-ISSN 2721-9658

Volume 3 Nomor 1 Juni 2021

process of learning, assessing the results of learning, guiding and training, and conducting research and serving the community. ${ }^{6}$ Educators in question are teachers and lecturers as professionals as holders of professions in the field of education. As stated in Republic of Indonesia Law No. 14 of 2005 concerning Teachers and Lecturers, teachers are professional educators with the main task of educating, guiding, directing training, assessing, and evaluating students in early childhood education, formal education, basic and secondary education. Whereas regarding the qualifications of teachers is also strengthened in the Law. Recognition of the position of the teacher as a professional is proven by an educator certificate. ${ }^{7}$

Teachers as the profession of the education profession, in carrying out their profession must have competence as stated in Law No. 14 of 2005 concerning Teachers and Lecturers. Article 10 Paragraph (1) of the Law states that teacher competencies include pedagogical competencies, personality competencies, social competencies, and professional competencies obtained through professional education. ${ }^{8}$

Malaysia has made many efforts to answer the teaching profession's questions. The latest development of the policy to transform Malaysian education can be seen in government actions launching a blueprint education strategy called the Education Development Master Plan (2006-2010) and the National Education Blueprint (2013-2025) which aims to improve Malaysian education standards and quality. Among the core strategies for improving the quality of education make teaching a prestige profession to ensure that schools will have quality teachers to improve the quality of education in the school system. ${ }^{9}$

There are several common elements in the world's most successful education policy system that focus on developing teacher professionalism as an important field of quality education. These include extensive opportunities for formal and informal professional development, professional learning and collaboration, ongoing professional development activities, and teacher involvement in curriculum decision making and teaching practices. ${ }^{10}$

The involvement of the teacher profession in educational policy reform initiatives has become one of the important components for the development of education, especially in Asian

\footnotetext{
${ }^{6}$ Undang-undang Nomor 20 Tahun 2003 tentang Sistem Pendidikan Nasional.

7 Undang-undang Nomor 14 Tahun 2005 tentang Guru dan Dosen.

8 Undang-undang Nomor 14 Tahun 2005 tentang Guru dan Dosen.

9 Jamil, H. (2014). Teacher is Matter for Education Quality: A Transformation of Policy for Enhancing the Teaching Profession in Malaysia. CICE Hiroshima University, Journal of International Cooperation in Education, Vol.16 No.2 (2014) pp.181 - 196.

10 Wei, R. C., Andree, A., \& Darling-Hammond, L. (2009). How nations invest in teachers. Educational Leadership, 66 (5), $28-33$.
} 


\section{คКคDEMIKค \\ Jurnal Manajemen Pendidikan Islam}

INSTITUT AGAMA ISLAM SUNAN KALIJOGO MALANG

P-ISSN 2622-9293 / E-ISSN 2721-9658

Volume 3 Nomor 1 Juni 2021

countries which are currently experiencing socio-economic and cultural transformation. ${ }^{11}$ In the context of policy, the increasing attention to the development of Malaysian education to improve the teaching profession can be understood as a continuous effort to achieve the ultimate goal of improving the quality and standards of education. In this regard, policies that lead to the professional development of Malaysian teachers cover various fields of action and discourse, from the central government, to places where practice is resolved and influenced by changes in educational needs and teacher professionalism, as well as social, political and economics of education. 12

Apart from the country's small geographical size, Singapore's economy is one of the most prosperous in the world. Not only is it ranked as the best country in Asia in the world to do business, but Singapore is also turned on as a high-performance education system with features that other systems can learn from. ${ }^{13}$ The organization for the Cooperation and Development Economy also commented on the strong link between education and economic development in Singapore, as well as between policy formulation and policy implementation.

The MOE oversees and manages all Singapore public schools and has a strong supervisory role for private schools. In 2015, the island state had 182 primary schools, 46 of which were government-funded private schools, and 154 secondary schools, 31 of which were government-funded private institutions. Singapore is able to design a comprehensive strategy for developing high-quality education systems, and at the center of this approach are trained and supported by both teachers and school leaders. ${ }^{14}$

Knowing that teacher quality makes the biggest difference in student achievement, the school system is most effective in investing in professional and personal development of educators. ${ }^{15}$ Singapore sponsors selected candidates, available lines of teacher education and career development pathways. This is supported by their respective frameworks to ensure that

11 The involvement of the teacher profession in educational policy reform initiatives has become one of the important components for the development of education, especially in Asian countries which are currently experiencing socio-economic and cultural transformation (Petras, Jamil \& Mohamed, 2012; Thair \& Treagust, 2003)

12 Jamil, H. (2014). Teacher is Matter for Education Quality: A Transformation of Policy for Enhancing the Teaching Profession in Malaysia. CICE Hiroshima University, Journal of International Cooperation in Education, Vol.16 No.2 (2014) pp.181 - 196.

13 Barber, M., \& Mourshed, M. (2007). How the world's best-performing school systems come out on top. New York, NY: McKinsey \& Company Society.

${ }^{14}$ Darling-Hammond, L. (2013). Developing and sustaining a high-quality teaching force. New York, NY: Asia

15 Mizell, H. (2010). Why professional development matters. Oxford, UK: Learning Forward. 


\section{คКค口EMIKค \\ Jurnal Manajemen Pendidikan Islam}

INSTITUT AGAMA ISLAM SUNAN KALIJOGO MALANG

P-ISSN 2622-9293 / E-ISSN 2721-9658

Volume 3 Nomor 1 Juni 2021

the prospects for each teacher's career development are carefully designed for each individual, allowing each individual to fully realize his potential.16

\section{RESEARCH METHODS}

This article is made by reviewing and gathering information from various references both books, articles and journals that are used as materials in studying and adding conceptually insight that is related to the management of educator quality assurance. After gathering information and through a series of literature studies and thought processes, all the theories, concepts, facts and information obtained are reviewed in the implementation of educator quality assurance management systems which are then integrated into one scope of discussion that is able to answer the author's curiosity regarding the quality assurance system educators to meet the quality standards of Indonesian education through education studies that have been conducted in Malaysia and Singapore.

\section{DISCUSSION}

\subsection{Teacher's position}

The teacher's profession is held by someone who is consciously responsible for educating, teaching and guiding students. ${ }^{17}$ They also have to have the ability to design learning programs and be able to organize and manage classes so that students can learn and eventually reach maturity as the ultimate goal of the education process.

As the main figure in the education process at school, the teacher plays a major role in determining the success of students, especially in relation to the process of achieving good learning outcomes. ${ }^{18}$ The teacher is the most influential component in creating quality learning processes and results. The main task of a teacher is to educate, teach, guide, direct, train, assess, and evaluate students. In carrying out its duties, teachers apply expertise, skills that meet certain quality standards or norms obtained through professional education. ${ }^{19}$

\footnotetext{
16 Low, E-L., and Tan, O-S. (2017). Teacher Education Policy: Recrutment, Preparation and Progression. SPRINGER Teacher Education in the 21st Century Singapore's Evolution and Innovation. ISBN : 978-981-10-3384-1

17 Hamzah, B. U (2008). Profesi kependidikan problema, solusi, dan reformasi pendidikan di Indonesia). Jakarta : PT Bumi Aksara.

18 Yusuf, M. Dan Ruslan. (2014). Pengaruh kompetensi profesional guru biologi yang telah tersertifikasi terhadap hasil belajar siswa di sma se-kota ternate. Jurnal Bio Edukasi 3(1) ISSN 2301-4678.

${ }^{19}$ Hidayah, F. (2013). Perbedaan tingkat efficacy ditinjau dari status sertifikasi pada guru sekolah menengah atas di Tuban. Jurnal Psikologi Pendidikan 2(1).
} 


\section{คКค口EMIKค \\ Jurnal Manajemen Pendidikan Islam}

INSTITUT AGAMA ISLAM SUNAN KALIJOGO MALANG

P-ISSN 2622-9293 / E-ISSN 2721-9658

Volume 3 Nomor 1 Juni 2021

Professional teachers are people who have special abilities and expertise in the field of teacher training so that they are able to perform their duties and functions as teachers with maximum abilities. ${ }^{20}$ The qualifications of teacher education are in accordance with the minimum prerequisites determined by the requirements of a professional teacher. Teacher and Lecturer Law No. 14 of 2005 explains that a professional is a job or activity carried out by a person and becomes a source of income for life that requires expertise, skills, or skills that meet certain quality standards or norms and requires professional education. ${ }^{21}$

The nature of professional teachers is teachers who are able to provide the best service for their students with their special abilities, so that students can receive and understand the delivery of the material provided. ${ }^{22} \mathrm{~A}$ teacher is not only required to have educative technical skills in carrying out his duties, but also must have a reliable character so that it can be a role model for students, families, and society. The development of teacher professional characters encourages the development of teacher potential continuously and continuously in accordance with the teaching needs of each teacher.

\subsection{Educator Quality Assurance in Malaysia}

\subsubsection{Selection of Malaysian Educators (MedSI)}

Providing quality education and improving overall student achievement is the mission of the Ministry of Education (MOE) in Malaysia. To fulfill this mission, the teachers play an important role in implementing the policy.23 Efforts to improve the teaching of traditional practices and improve teacher choice are some of which are educational reforms that aim to enrich the teaching profession. Today's teaching profession is becoming more challenging, so it requires teachers to continue to equip themselves with renewal of knowledge and abilities. With this in mind, the MOE intends to employ all individuals who are capable and will then teach future generations.

The road to becoming a teacher begins when an individual first chooses to teach as a profession, both for idealistic and practical reasons. Therefore, the process of selecting prospective teachers needs to be done strictly. The implementation of the Malaysian Educator Selection Educator (MEdSI) test and interview for screening the training of teacher

\footnotetext{
20 Usman, M. U. (2010). Menjadi guru profesional. Bandung: PT. Remaja Rosda Karya.

21 Undang-undang Nomor 14 Tahun 2005 tentang Guru dan Dosen.

22 Dewi, T. A. (2015). Pengaruh profesionalisme guru dan motivasi kerja terhadap kinerja guru ekonomi sma se-kota Malang. Jurnal Pendidikan Ekonomi 3(1) ISSN: 2442-9449.

${ }^{23}$ Hashim, H., Damio, S. M., Hussin, N. (2013). Malaysian Educators Selection Inventory (MEdSI) Certified Interviewers' Perspectives on its Implementation: A Preliminary Study. International Conference on University Learning and Teaching (InCULT 2012). ELSEVIER Procedia - Social and Behavioral Sciences 90, 171 - 177.
} 


\section{คКคDEMIKค \\ Jurnal Manajemen Pendidikan Islam}

INSTITUT AGAMA ISLAM SUNAN KALIJOGO MALANG

P-ISSN 2622-9293 / E-ISSN 2721-9658

Volume 3 Nomor 1 Juni 2021

participants starting in the $2007 / 2008$ academic session described the government's efforts to achieve its inspirational goals. Teacher selection and Malaysian secondary school recruitment includes a potential applicant identification program, selection, training, certification and finally teacher recruitment. The target population is graduates of STPM (Secondary Education Certificate), Diploma graduates, Higher Education graduates and University graduates.

The development of teacher education and selection in Malaysia is closely related to the progress and progress of the national education system. The teacher education syllabus, recruitment of teacher training participants, duration of training, content and methods of training tend to vary with changes in the needs of the school system. ${ }^{24}$ The history of teacher education actually begins with the initial system of education, which refers to the Islamic education system. The first Islamic institution is the Quran school, followed by Pondok and Madrasah. After independence, the influence of the British education system still exists in this country. The government is building more schools to accommodate more students and there is an urgent need to recruit teachers to become staff of newly built classrooms. To address the problem of teacher shortages, they recruit teachers with academic qualifications as low as form 3 , and these teachers undergo part-time training during school and weekend vacations at the central regional training and training academy. For secondary schools, the government invites teachers from the UK and India. 25

\subsubsection{Teacher Professional Development in Malaysia}

The efforts to develop sustainable education have been carried out, namely, Malaysia launching the Education Development Master Plan 2006-2010 (PPIP 2006-2010) simultaneously with the Ninth Malaysia Plan ${ }^{26}$ and the National Mission to achieve the main goals of quality education for all. PPIP 2006-2010 consists of six strategic drives whose agenda to improve the teaching profession is among the core strategies to achieve the goal of improving the quality of education. That is clearly stated in PPIP 2006-2010, the role of

\footnotetext{
${ }^{24}$ Molly, N. and Lee, N. (2004). Malaysian teacher education into the new century. Reform of teacher education in Asia Pacific in the new Millenium: trends and Challenges. Education in the Asia-Pacific Region: Issues, Concerns and Prospects, Volume 3, 2, 81-91, DOI: 10.1007/978-1-4020-2722-2-6.

25 Molly, N. and Lee, N. (2004). Malaysian teacher education into the new century. Reform of teacher education in Asia Pacific in the new Millenium: trends and Challenges. Education in the Asia-Pacific Region: Issues, Concerns and Prospects, Volume 3, 2, 81-91, DOI: 10.1007/978-1-4020-2722-2-6.

26 Malaysia. (2006). Ninth Malaysia Plan 2006- 2010. Putrajaya: The Economic Planning Unit, Prime Minister's Department.
} 


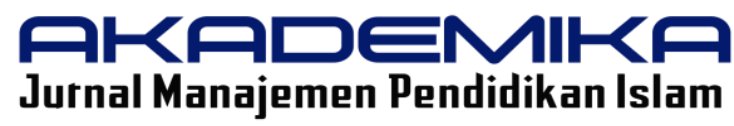

INSTITUT AGAMA ISLAM SUNAN KALIJOGO MALANG P-ISSN 2622-9293 / E-ISSN 2721-9658

Volume 3 Nomor 1 Juni 2021

teachers is increasingly important to achieve the goal of developing national education which is quality education for all.27

Central to this policy intention, the strategy is to increase teacher professionalism; a term that not only includes teacher knowledge, skills and experience, but also their qualities that are more tangible in terms of spiritual, social, intellectual and financial capital. This involves the ongoing efforts of the government in Indonesia to make the teaching profession one of the prestigious and respected professions in Malaysia. ${ }^{28}$

Picture 1. Malaysia Plan Education Development Conceptual Framework (2006-2010)

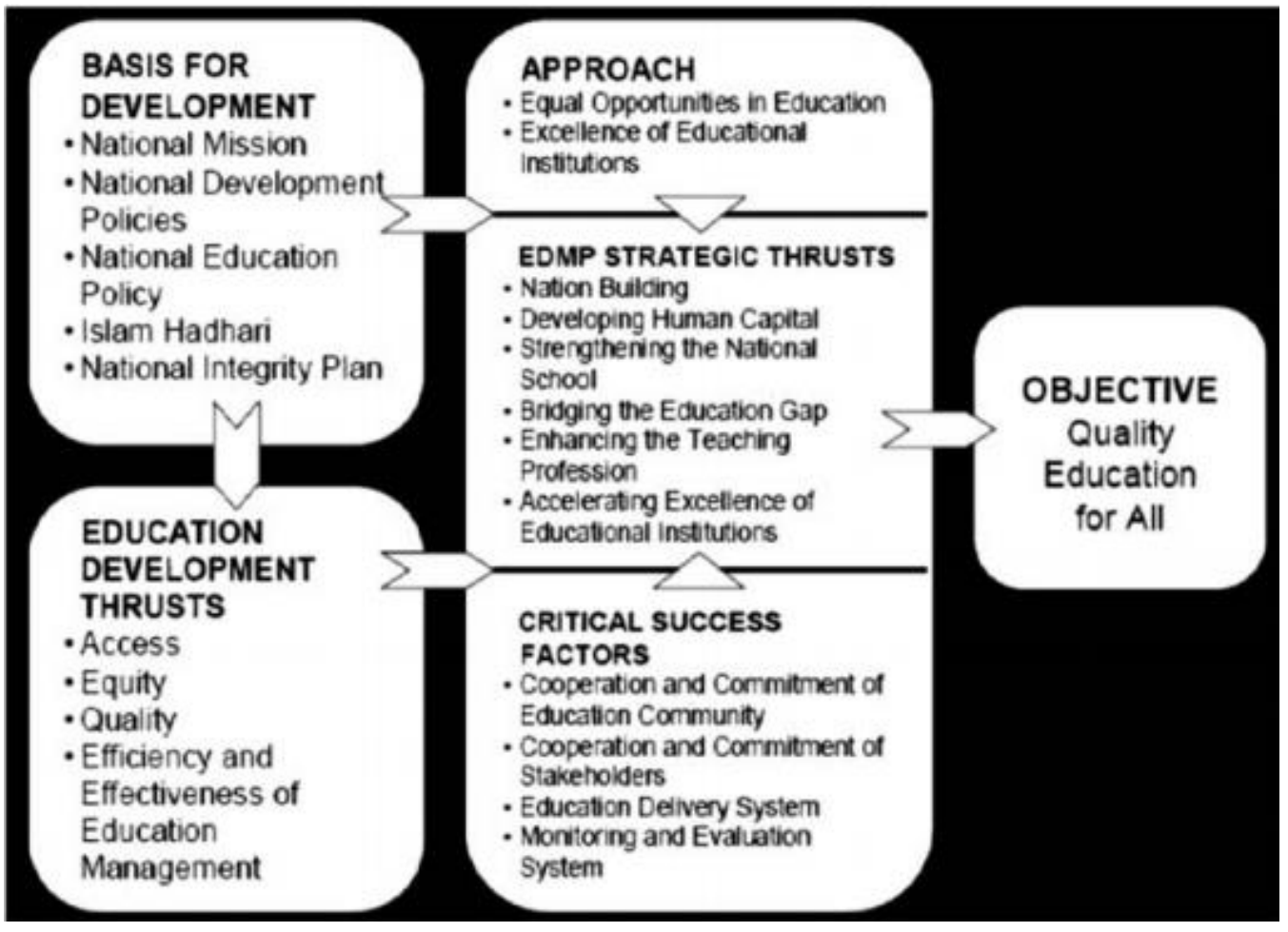

Source: Ministry of Education Malaysia (2006)

As professional development teachers (TPD) are problems that are present from the very beginning of preparation for the teaching profession ${ }^{29}$, most educational institutions in Malaysia are committed to supporting professionals developing their teacher's knowledge and

27 Ministry of Education Malaysia. (2006). Education Development Master Plan 2006-2010 (PPIP 2006-2010). Putrajaya: Ministry of Education Malaysia.

28 Jamil, H. (2014). Teacher is Matter for Education Quality: A Transformation of Policy for Enhancing the Teaching Profession in Malaysia. CICE Hiroshima University, Journal of International Cooperation in Education, Vol.16 No.2 (2014) pp.181 - 196.

29 Jovanova-Mitkovska, S. (2010). The need of continuous professional teacher development. Procedia Social and Behavioral Sciences, 2(2), 2921-2926. 


\section{คКค口EMIKค \\ Jurnal Manajemen Pendidikan Islam}

INSTITUT AGAMA ISLAM SUNAN KALIJOGO MALANG

P-ISSN 2622-9293 / E-ISSN 2721-9658

Volume 3 Nomor 1 Juni 2021

practices, so that they grow in quality to world teaching standards. At the center of the TPD problem, TPD policy acts as a template in the process of producing quality teachers. Originating from a strategic drive to improve the teaching profession, TPD policies are implemented in Malaysia through a continuous process of teacher professional development, starting from the beginning of the teacher's career, either through postgraduate study, non-credit courses, workshops, or other informal learning experiences. Malaysian teachers are encouraged and motivated to pursue courses in the critical and relevant fields by offering remuneration packages and potential promotions. This involved continuous efforts by the government in making efforts to have 100 percent of secondary school teachers and 80 percent as degree holders. ${ }^{30}$ Teachers are also encouraged to have Masters degrees and even PHD with various scholarship schemes offered by the Ministry of Education. In Malaysia today, most secondary school teachers are Masters or first-degree graduates, while primary school teachers are mostly first-level graduates or diplomas.

Regardless of this achievement, a number of possible challenges have hit teachers and quality teaching practices identified as follows : i) Apart from Malaysian teacher certification, the number of inadequately trained teachers, especially in primary schools, can have a negative impact on quality instructions; ii) Although Malaysian teachers are paid relatively well, there is still a need to encourage more high-quality graduates into the teaching profession; iii) Inservice training is common in Malaysia, and teachers are formally required to receive the training every year. However, the actual number of teachers benefiting from valuable inservice training programs can further improve. This is especially true for elementary school teachers; iv) In general there is a high level of commitment from teachers to their students, but the lack of administrative support in schools, especially primary schools, and / or the advantages of administrative work for teachers can hamper the ability of Malaysian Teachers to devote more time to students they; v) While the principle of "meritocracy" is accepted and respected, there are questions about the possible negative effects of allocating school funds based on practically narrow academic measures. ${ }^{31}$

\subsubsection{Malaysian Teacher Welfare}

In overcoming disparities in qualifications, salaries and prestige between primary and secondary schools, teachers are divided by various groups, positions and incentives, such as

\footnotetext{
30 UNESCO. (2008). Status of Teacher Education in the Asia-Pacific Region. Prepared by International Reading Association.

31 UNESCO. (2013). Malaysia Education Policy Review. Abridged Report.
} 
primary school teachers and assistants, 'superior teachers', important subject teachers, teachers who teach in remote locations, and several age groups based on years in service. ${ }^{32}$ This policy initiative is being sought to provide high-quality teachers to provide quality education to students. He hopes to have a direct impact to develop a strong status of a teacher and have an impact on their professional identity in relation to their prestige. ${ }^{33}$

In improving the professional status of teachers and improving career paths for teachers, teacher and teacher educators whose performance is very well valued are rewarded through a multi-level remuneration system, including bonuses. There is also a master scheme teacher (promotion scheme; ET scheme) which was introduced in 1993 and provides professional recognition and service to teachers. The department head identifies excellent teachers for observation and assessment by the Federal Inspectorate of the school, which in turn proves the teaching performance of the teachers. Objectives for ET (very good promotion schemes are as follows: i) recognizing teachers who are good in their fields or subjects; ii) to improve the quality of teaching; iii) be a role model for other teachers; iv) to improve school excellence by utilizing ET experience and expertise, $v$ ) broadening the horizon of promotion in education services; vi) promoting teachers without leaving their teaching or changing into administrative tasks. ${ }^{34}$

\subsection{Teacher Professional Development in Singapore}

\subsubsection{Teacher Recruitment in Singapore}

To meet the changing needs and demands of the twenty-first century learning environment, it is very important for Singapore to be able to attract, choose and retain the people needed to educate the younger generation. While the MOE took over responsibility for the recruitment, preparation, certification, appointment and deployment of teachers for Singapore schools, this was not done separately but by partnering with NIE, schools, and other stakeholders (eg teachers, parents, other government ministries). , universities and the private sector). As sought Singapore continues to provide high-level qualifications among teachers, involvement like this goes beyond those associated with licensing standards that are common

32 Petras, Y., Jamil, H., \& Mohamed, A. R. (2012). How do teachers learn? A study on the policy and practice of teacher professional development in Malaysia. KEDI Journal of Educational Policy, 9(1), 51 - 70.

33 Rao, R. R., \& Jani, R. (2011). Teacher allocation and equity in Malaysian schools. International Journal of Institutions and Economies, 3(1), $103-112$.

${ }^{34}$ Hamzah, S. G., Mohamad, H., \& Ghorbani, M. R. (2008). Excellent Teachers' Thinking Model: Implications for Effective Teaching. Australian Journal of Teacher Education, 33(4), 11 - 27. 


\section{คКค口EMIKค \\ Jurnal Manajemen Pendidikan Islam}

INSTITUT AGAMA ISLAM SUNAN KALIJOGO MALANG

P-ISSN 2622-9293 / E-ISSN 2721-9658

Volume 3 Nomor 1 Juni 2021

in other countries. ${ }^{35}$ Every year, KLH receives feedback from schools and the data itself makes strategic estimates about recruitment, plans for new schools, initiatives and programs. This section details national teaching standards from recruitment in preparation for progress in the teaching career.

The MOE recruited teachers from the top third of each graduating class group who qualified for higher education, and only one in eight applicants interviewed was accepted. In addition to satisfying basic academic standards, prospective teachers must also have the talent and interest in teaching. This is confirmed in interviews held by KLH officers and school principals and experienced teachers. ${ }^{36}$ Throughout the year, KLH organizes several recruitment seminars called 'Teaching as a Career' for applicants who are interested in attending as well as opportunities for them to ask questions. Prospective students can apply to one of the graduates or non-graduate teacher education programs depending on their academic qualifications. The Ministry also invested heavily in teaching branding as one that was closely related to the important mission of nation-building. For example, bus ads about teaching have the following tagline, 'Forming the nation's future: One student at a time'.

\subsubsection{Teacher Professional Development in Singapore}

The teacher has access to several types of professional development opportunities. They can increase their training through courses at the National Institute of Education (NIE) or at the Singapore Teacher Academy, which was established by the Ministry of Education and is an organization dedicated to providing conferences, forums and seminars for teachers, or study leave for those wishing to pursue a degree program . These programs range from inservice training to online classes on various subjects related to teaching. The Ministry and NIE also offer scholarship opportunities for teachers who are seeking MA and PhD degrees in Singapore or abroad, whether full or part time. Teachers can participate in professional development as much as 100 hours per year.

\subsubsection{Teacher Early Education and Training}

There is only one teacher training institution in Singapore - National Institute of Education (NIE). NIE is located at Nanyang University of Technology, one of the most prestigious institutions in the hierarchy of Singapore's higher education institutions. All

35 Low, E-L., and Tan, O-S. (2017). Teacher Education Policy: Recrutment, Preparation and Progression. SPRINGER Teacher Education in the 21st Century Singapore's Evolution and Innovation. ISBN : 978-981-10-3384-1

36 Teo, C. H. (2000). Speech by Radm (NS) Teo Chee Hean, Minister for Education \& 2nd Minister for Defence, at the 2nd Teaching Scholarship Presentation Ceremony. 


\section{คКค口EMIKค \\ Jurnal Manajemen Pendidikan Islam}

INSTITUT AGAMA ISLAM SUNAN KALIJOGO MALANG

P-ISSN 2622-9293 / E-ISSN 2721-9658

Volume 3 Nomor 1 Juni 2021

teachers are trained at the National Institute of Education (NIE), which offers undergraduate and postgraduate degrees. Eighty percent of applicants who have received a bachelor's degree in the subject they will teach before entering the teacher education program. During their training, candidate teachers receive a monthly allowance equivalent to $60 \%$ of the salary of novice teachers, and their tuition is borne by the Ministry of Education. After they complete the training, the teachers must commit to a full three years at work.

Prospective teachers who already have a bachelor's degree in an approved field of study must complete one of the teacher education programs at the NIE, as well as pass or be excluded from the Skill Test Entrance. There are various programs for prospective teaching that are different, depending on the candidate's education level when entering the program. These include a Diploma in Education, a Postgraduate Diploma in Education and a Bachelor of Arts / Science (Education), and a range of two to four years. Teachers with other credentials, such as an A-level (high school leave) exam) or a polytechnic degree, must complete an NIE degree program. The programs at NIE are focused on pedagogy and connections between educational subjects, not at the advanced level of academic training in certain subjects. What says that one cannot become a teacher in Singapore without mastering subjects to be taught at a high level, and at least a year of teaching that is challenging in teaching skills. This curriculum is constantly updated to reflect the changing needs of the Singapore education system.

\subsubsection{Teacher's Career Ladder}

There are three-way teaching careers that can be pursued in Singapore: the path of teaching, path leadership and specialist pathways. In the teaching pathway, teachers strive to become Principal Teachers of Teachers In the path of leadership, teachers can be promoted from leadership positions in schools to the position of Director General of Education. At the track specialist, the teacher focuses on research and teaching policies, with the highest level position being the Chief Specialist. There are 13 levels in each song. The first three levels are considered "general"; the next two stages are "senior" and then the top eight are "super senior". At each level, there are salary increases and additional training and guidance opportunities. For the first three years of teaching, all teachers receive annual salary increases. After that, salary increases are only available as part of a promotion along the career path.

The teacher is not automatically promoted to the next level. Teacher performance on the Education Performance Management System (EPMS) determines when they are eligible for a career ladder. EPMS includes annual evaluations in three areas: Professional Practice, 
Management of Leadership and Personal Effectiveness. Teachers are expected to set and fulfill personal goals for their work, and show improvements in the competency rubric during their teaching observations.

EPMS is also used to determine teacher compatibility for career paths. All teachers are observed for three years to determine which career path is best for them. But after the teacher is assigned a career path, they can make lateral steps if they feel the path is not suitable for them. Talent and leadership potential are identified early, and these teachers are then prepared for future leadership roles. Singapore schools operate with the belief that poor leadership is the main reason for school failure, and by choosing talented individuals early in their careers and investing in them, schools can avoid this problem. This training often involves promotion to head of department at a young age, recruitment to several academic and administrative committees, assignments in the Ministry of Education and six-month executive leadership courses at NIE.

\subsubsection{Teacher Welfare in Singapore}

Most teacher salaries in Singapore are commensurate with other professions. The maximum salary for the lower middle teacher is double the GDP per capita, indicating that the teacher's compensation is generally quite strong. The Ministry of Education monitors teacher salaries in Indonesia related to other professional salaries, and adjusts them accordingly to ensure they are competitive. Successful teachers have the opportunity to get a retention bonus, which can range from $\$ 10,000$ - \$36,000 every three to five years, and performance bonuses, which can reach up to $30 \%$ of their basic salary. Feasibility for this bonus is determined through a rigorous annual evaluation that also serves as a basis for coaching and mentoring among teachers. Including bonuses, annual capital salaries for teachers aged 25-29 are \$ 43,563 in 2009 , and the maximum salary is $\$ 77,693$. This is better compared to the OECD average of $\$ 41,701$ for middle to upper middle teacher careers and a maximum salary of $\$$ 51,317 . Teacher compensation depends in part on where they are on various career ladders available to them. The promotion of this career ladder depends entirely on the indicated performance and potential. 


\section{คКค口EMIKค \\ Jurnal Manajemen Pendidikan Islam}

INSTITUT AGAMA ISLAM SUNAN KALIJOGO MALANG

P-ISSN 2622-9293 / E-ISSN 2721-9658

Volume 3 Nomor 1 Juni 2021

\section{DISCUSSION AND CONCLUSION}

Professional teachers are people who have special abilities and expertise in the field of teacher training so that they are able to perform their duties and functions as teachers with maximum abilities. ${ }^{37}$ The qualifications of teacher education are in accordance with the minimum prerequisites determined by the requirements of a professional teacher. Teacher and Lecturer Law No. 14 of 2005 explains that a professional is a job or activity carried out by a person and becomes a source of income for life that requires expertise, skills, or skills that meet certain quality standards or norms and requires professional education. In the implementation of teacher professional development to achieve maximum ability a strategy is needed to become a professional teacher. ${ }^{38}$

The development of educator quality assurance is adjusted to the school strategy and is supported by good quality teachers and follows educational needs that are always developed and prepared in advance through the School Revenue and Expenditure Plan (SREP). The strategy for teacher professional development is inseparable from the role of schools which emphasizes the existence of a continuous quality improvement program. The strategy used is the goal of national education that continues to develop itself in accordance with regional conditions, school conditions, and future potential. Teacher professional development is a process of activities in order to adjust the professional abilities of teachers with the demands of education and teaching. ${ }^{39}$

In addition to teacher professional development strategies carried out by institutions, there are also activities carried out through professional organization forums by following Subject Teacher Consultation (STC) activities or seminars, workshops and training sessions conducted outside of teaching hours so as not to disturb the learning process in the implementation of professional development carried out by teachers. According to Kartini (2011) factors that influence teacher professional development are: 1) training which can also be called education and training (training) and / or Subject Teacher Consultation (STC), 2) academic qualifications or also called educational background, 3) academic supervision or called continuous supervision, 4) principal leadership, 5) motivation, 6) welfare or

37 Usman, M. U. (2010). Menjadi guru profesional. Bandung: PT. Remaja Rosda Karya.

38 Undang-undang Nomor 14 Tahun 2005 tentang Guru dan Dosen.

39 Thalib, M. M. (2012). Pengembangan profesi, kecerdasan emosional dan sikap profesional guru sekolah dasar. Jurnal DIKDAS 1(1). 


\section{คКคDEMIKค \\ Jurnal Manajemen Pendidikan Islam}

INSTITUT AGAMA ISLAM SUNAN KALIJOGO MALANG

P-ISSN 2622-9293 / E-ISSN 2721-9658

Volume 3 Nomor 1 Juni 2021

compensation, 7) work ethic, 8) ability to use Information and Communication Technology (ICT).40

The implementation of educator quality assurance in Indonesia is in accordance with the strategies prepared by government agencies because in every implementation the mathematics teacher always gets direction from the school. By remembering the weight and complexity of building education, it is very important to make efforts to encourage and empower educators to become more professional. ${ }^{41}$

Teacher professional development through educational institutions (Education Authorities) requires the participation of all activities carried out in an effort to always improve the professionalism of the teachers' performance. The implementation of professional development in addition to the strategy of the school can also be carried out based on teaching needs and teacher development through independent activities and educational organization activities.

This is consistent with what Mujtahid (2009) revealed that the implementation of educational teacher professional development activities can be carried out through the following models: 1) Professional Development and Development; 2) Participation in Scientific Activities; and 3) Activating Professionals in Professional Organizations. The implementation of teacher professional development activities is basically an increase in the quality of the dimensions of a teacher's competence. The competency in question is to cover the four professional competencies of the teacher. ${ }^{42}$

School readiness in educator quality assurance is also very important in the preparation of the SREP which has raised funds in the development of teacher professions that underlie the achievement of the development of four teacher professional competencies. Teacher professional development is forced through activities in developing process standards and developing standards for educators and education personnel.

Although the activity of educator quality assurance prepared by the government and the school is good, it does not rule out any obstacles. Nevertheless, schools always monitor the readiness of teachers through assessment of teacher subject performance. The values of the teacher's performance based on the teacher's PK report and evaluation which includes 4

40 Kartini. K. (2011). Faktor-faktor yang mempengaruhi kompetensi profesional guru di SMK Negeri Losarang kabupaten Indramayu. Tesis FISIP Program Pascawarjana Universitas Indonesia.

41 Mustofa. (2007). Upaya Pengembangan Profesionalisme Guru Di Indonesia. Jurnal Ekonomi dan Pendidikan 4(1). Universitas Negeri Yogyakarta.

42 Mujtahid. (2009). Pengembangan Profesi Guru. Malang: UIN Press. 
competencies that must be possessed by the teacher include 1) Pedagogic Competence; 2) Personality Competence; 3) Social Competence; and 4) Professional Competence, where the assessment addresses that the teacher in carrying out his profession has been very good and in accordance with what is expected. 


\section{REFERENCES}

Barber, M., \& Mourshed, M. (2007). How the world's best-performing school systems come out on top. New York, NY: McKinsey \& Company

Darling-Hammond, L. (2013). Developing and sustaining a high-quality teaching force. New York, NY: Asia Society.

Dewi, T. A. (2015). Pengaruh profesionalisme guru dan motivasi kerja terhadap kinerja guru ekonomi sma se-kota Malang. Jurnal Pendidikan Ekonomi 3(1) ISSN: 2442-9449.

Hamzah, S. G., Mohamad, H., \& Ghorbani, M. R. (2008). Excellent Teachers' Thinking Model: Implications for Effective Teaching. Australian Journal of Teacher Education, 33(4), 11 $-27$.

Hamzah, B. U (2008). Profesi kependidikan problema, solusi, dan reformasi pendidikan di Indonesia). Jakarta : PT Bumi Aksara.

Hashim, H., Damio, S. M., Hussin, N. (2013). Malaysian Educators Selection Inventory (MEdSI) Certified Interviewers' Perspectives on its Implementation: A Preliminary Study. International Conference on University Learning and Teaching (InCULT 2012). ELSEVIER Procedia - Social and Behavioral Sciences 90, 171 - 177.

Hidayah, F. (2013). Perbedaan tingkat efficacy ditinjau dari status sertifikasi pada guru sekolah menengah atas di Tuban. Jurnal Psikologi Pendidikan 2(1).

Jamil, H. (2014). Teacher is Matter for Education Quality: A Transformation of Policy for Enhancing the Teaching Profession in Malaysia. CICE Hiroshima University, Journal of International Cooperation in Education, Vol.16 No.2 (2014) pp.181 - 196.

Jovanova-Mitkovska, S. (2010). The need of continuous professional teacher development. Procedia - Social and Behavioral Sciences, 2(2), 2921-2926.

Kartini. K. (2011). Faktor-faktor yang mempengaruhi kompetensi profesional guru di SMK Negeri Losarang kabupaten Indramayu. Tesis FISIP Program Pascawarjana Universitas Indonesia.

Low, E-L., and Tan, O-S. (2017). Teacher Education Policy: Recrutment, Preparation and Progression. SPRINGER Teacher Education in the 21st Century Singapore's Evolution and Innovation. ISBN : 978-981-10-3384-1

Malaysia. (2006). Ninth Malaysia Plan 2006- 2010. Putrajaya: The Economic Planning Unit, Prime Minister's Department.

Ministry of Education Malaysia. (2006). Education Development Master Plan 2006-2010 (PPIP 2006-2010). Putrajaya: Ministry of Education Malaysia.

Mizell, H. (2010). Why professional development matters. Oxford, UK: Learning Forward.

Molly, N. and Lee, N. (2004). Malaysian teacher education into the new century. Reform of teacher education in Asia Pacific in the new Millenium: trends and Challenges. Education in the Asia-Pacific Region: Issues, Concerns and Prospects, Volume 3, 2, 81 91, DOI: 10.1007/978-1-4020-2722-2-6.

Mujtahid. (2009). Pengembangan Profesi Guru. Malang: UIN Press.

Mustofa. (2007). Upaya Pengembangan Profesionalisme Guru Di Indonesia. Jurnal Ekonomi dan Pendidikan 4(1). Universitas Negeri Yogyakarta. 
Petras, Y., Jamil, H., \& Mohamed, A. R. (2012). How do teachers learn? A study on the policy and practice of teacher professional development in Malaysia. KEDI Journal of Educational Policy, 9(1), 51 - 70.

Rao, R. R., \& Jani, R. (2011). Teacher allocation and equity in Malaysian schools. International Journal of Institutions and Economies, 3(1), 103 - 112.

Sumarsono, R.B. (2014). Pengembangan profesi tenaga pendidik melalui karya ilmiah dalam rangka menuju pendidikan yang bermutu. Jurnal Administrasi Pendidikan FIP UM Prosiding Seminar Nasional.

Teo, C. H. (2000). Speech by Radm (NS) Teo Chee Hean, Minister for Education \& 2nd Minister for Defence, at the 2nd Teaching Scholarship Presentation Ceremony.

Thair, M., \& Treagust, D. (2003). A brief history of a science teacher professional development initiative in Indonesia and the implications for centralized teacher development. International Journal of Educational Development, 23(2), 201 - 213.

Thalib, M. M. (2012). Pengembangan profesi, kecerdasan emosional dan sikap profesional guru sekolah dasar. Jurnal DIKDAS 1(1).

Trianto. (2010). Pengantar Penelitian Pendidikan bagi Pengembangan Profesi Pendidikan dan Tenaga Kependidikan. Jakarta : Kencana Prenada Media Group.

Undang-undang Nomor 20 Tahun 2003 tentang Sistem Pendidikan Nasional.

Undang-undang Nomor 14 Tahun 2005 tentang Guru dan Dosen.

UNESCO. (2008). Status of Teacher Education in the Asia-Pacific Region. Prepared by International Reading Association.

UNESCO. (2013). Malaysia Education Policy Review. Abridged Report.

Usman, M. U. (2010). Menjadi guru profesional. Bandung: PT. Remaja Rosda Karya.

Wei, R. C., Andree, A., \& Darling-Hammond, L. (2009). How nations invest in teachers. Educational Leadership, 66 (5), 28 - 33.

Yusra. (2014). Upaya peningkatan efisiensi tenaga guru profesional dalam pencapaian mutu pendidikan. Jurnal 10(1)

Yusuf, M. Dan Ruslan. (2014). Pengaruh kompetensi profesional guru biologi yang telah tersertifikasi terhadap hasil belajar siswa di sma se-kota ternate. Jurnal Bio Edukasi 3(1) ISSN 2301-4678. 